\title{
Editorial \\ Latino/as in the South: Immigration, integration and identity
}

Latino Studies (2012) 10, 1-10. doi:10.1057/lst.2012.19

What does it mean to be invisible? Consider the following description of the impact of Katrina on Latino/as in New Orleans:

Hurricane Katrina hit Latinos harder than it hit most other ethnic communities. Many Spanish-speaking Latinos did not even evacuate almost all storm warnings were broadcast in English. Many immigrant Latinos lost papers, a relative, or a job to which their immigration status was tied, jeopardizing their ability to receive emergency aid. Even though undocumented immigrants have the right to relief like food, health care, and refuge in the wake of a disaster, immigration officers raided at least two Red Cross shelters. Relief workers neglected an entire apartment complex in a New Orleans suburb, assuming its residents were undocumented and ineligible for housing assistance, neither of which turned out to be the case. Linguistic isolation and the legal complexities of non-citizens make all Latinos vulnerable to being excluded from federal aid. (Petri, 2009)

Certainly, the devastating symbolism of both the natural and, particularly, the human destruction of New Orleans in the aftermath of Katrina, brought into sharp relief the ongoing presence of racial prejudice and discrimination in social relations in the US South. After all, in the course of numerous days of hunger and thirst, of unambiguous abandonment and official indifference, the extent of the dispensability of poor African American and Latino/a citizenvictims of Katrina was forcefully and visibly highlighted for all Americans across the nation.

This special issue brings together articles presented at the conference on "Latino/as in the South: Immigration, Integration and Identity," co-sponsored by Latino Studies and the University of Alabama at Tuscaloosa. We are very grateful to Professor Michael Innis-Jiménez, who co-hosted this journal's conference and workshop at the University of Alabama at Tuscaloosa, in February 2010. His invaluable support contributed significantly to the 
realization of the participants' common objective: to make more visible the importance of the growing presence and the experiences of Latino/a immigrants and their children in the US South today.

As several authors note in their contributions to this issue, the US South is undergoing significant transformation as a result of the changes stemming from the growing numbers and ongoing struggle of Latino/as for their right to have rights and the simultaneous legal and societal backlash against them. This process is serving to bring into sharp relief both the extent to which the region has changed since the Civil Rights era and how much nevertheless remains the same. The changes are framed both by the traditional Black/ White paradigm that has long determined racial and social relations in the South, and a concomitant collective memory of slavery, of Jim Crow segregation, of the Ku Klux Klan's lynchings and the bloody persecutions and murders of African Americans. Cities and towns in the states of the US South continue to be impacted by the region's violent legacy, as well as by the ongoing repercussions in the American national experience, of African Americans' ongoing struggle to affirm themselves as full citizens of the nation. Indeed, the South continues to play a significant role as both a "social barometer" of the scourge of racism in US society (Lippard and Gallagher, 2011), and as a mirror of the nation's racialized self-definition, identity and imagination.

Central to both the Conference and this double issue is an effort to understand how the growing presence of Latino/as in the region has impacted on its historical binary paradigm of race and the meaning(s) attributed to Blackness that have permeated its daily life, leaving an indelible mark throughout the South and on the national identity as a whole. The authors explore historical and contemporary issues affecting the lived experiences of the growing population of Latino/as in what some have called the "Nuevo New South," and examine the changing nature of the region's racial and ethnic relations from a broad variety of theoretical and disciplinary perspectives. In so doing, they address questions such as: To what extent is the growing presence of Latinas and Latinos affecting the political, socioeconomic and cultural life in the US South? And, to what extent and in what ways have various sectors in the southern states embraced or rejected the growing Latino populations at the local level today?

It is certainly no secret that the political will to end segregation in the $1950 \mathrm{~s}$ was influenced by the shame of a nation that had fought a war against racism abroad, while upholding its violent and undemocratic practices at home. Although the post-Civil Rights era has not erased the inequalities between Blacks and Whites, the presence of Latino/as in the South has led today to a new configuration of the social dynamics in the region - one that raises questions about the changing nature of immigrant integration and its impact on US society, as well as about the nature of belonging and its political expression in citizenship in the current context of neoliberal globalization. 
Paradoxically, the end of legal discrimination in the United States primarily signaled the unchallenged entrenchment of racism in social relations. The dualistic Black/White biological racism that justified legal segregation until 1954 has since been undermined by the emergence of a new ideology of "social racism" embedded in a new kind of social relations, grounded in daily life, that is key to understanding and addressing the ongoing context of poverty and deprivation of large sectors of the US population, including Latino/as and African Americans in the South and, indeed, in the nation as a whole.

It is thus fitting that this issue begin with the poignant account by Saket Soni, Director of the New Orleans Workers' Center for Racial Justice, of the on-theground socio-racial experiences and relations between Black and Latino workers. Soni vividly documents their struggle for justice and equality in a context of ongoing disregard for the rights, dignity and humanity of both groups. As one African American activist emphasizes in response to a Latino worker's frustration about immigrants' lack of legal status, "We got citizenship ... They gave us legal status. And look at what happened to us."

Soni takes as his point of departure the reality that African Americans have been racially "locked out" of the reconstruction of New Orleans, whereas Latino/a guest workers have been racially "locked in" to the exploitative labor conditions created by the contractors and developers who are rebuilding the region. Describing the role of labor leaders and organizers in New Orleans and across the South, "in the spaces in which human beings are most stripped of dignity," he provides concrete examples of the struggle against the atrocious living and working conditions and the outrageous exploitation and humiliation suffered by Latino/a immigrant workers including "holding workers captive in labor camps; confiscating their passports; subjecting them to surveillance; leasing workers for a profit in violation of morality and the law; and trafficking workers into conditions of imprisonment." His essay details the response of workers and organizers as they fight to secure both the integration of Latino/as and the necessary policies to expand democracy and ensure that they, like African American and other workers, can achieve a life grounded in human rights and dignity.

The importance of the regional context within which the above developments unfold cannot be overstressed. In this issue, Néstor Rodríguez and Julie Weise, respectively, provide sociological and historical perspectives on the significance of Latino/as' growing presence in a region that to this day dominates the national imagination and discussions on institutional racism and the various forms that racial prejudice and discrimination have taken in the course of US history. Although both emphasize that the presence of Mexican and other Latino/a immigrant laborers can be traced to the early twentieth century, Rodríguez pinpoints Latino/as' increased immigration from Mexico, Central America and other parts of Latin America and the Caribbean during the 1990s as ultimately having created "two contrasting phases," in assessing the 
historical and contemporary impact of their presence on relations between African Americans and Latinos in the South. Noting that international, national and local developments all affect, although in different ways, the evolution of African American-Latino/a relations, Rodríguez uses Mexico as a case study of the role of conditions in immigrants' homelands in motivating contemporary labor emigration. He also discusses the impact and potential of recent federal and local immigration enforcement in shaping current and future relations between African Americans and Latinos.

Julie Weise argues that "Latinos have become protagonists in a narrative not of their own making," thus challenging "the claim of a rupture with the past" in recent academic and popular narratives of the Latino/a experience in the South. She notes that from early on, Latino/a presence in the region was the result of migration whether from Texas, California or the Southwest. Thus, she cautions that "the White South's long history of proclaiming 'New'-ness as a strategy toward historical amnesia should give us pause before adopting such a refrain." Although she recognizes that Latino/as are "standing in the shadow of slavery" to use Saket Soni's apt phrase, Weise emphasizes the need for a more accurate portrayal of Latino/as in the region, one that is framed through their own understanding of their experience.

Her article shows that in addition to immigrants from Latin America and the Caribbean, people of Mexican descent in the United States have long migrated to other parts of the country in search of work. As Weise explains, whereas some Latino/as saw the South as similar to other rural areas, for others migration was perceived as an opportunity to achieve economic mobility. Still others might view it either as a "site to escape the racializations of the Southwest and grow closer to Whiteness" or as a region that forces them to experience more intense relations with African Americans. From this perspective, Weise's article leads us to consider how "new" Latino/a migrants' "Nuevo South" really is. In so doing, she motivates a closer examination of the distinct experiences of Latino/as themselves in shaping our understanding of the changing nature of southern society, including race relations in the region.

The articles that follow exemplify the importance of acknowledging Weise's insight that "Latino migration to the South ... is in many ways the predictable result of a century of developments." And as such, Weise says, the way Latinos make sense of their experience is best understood by recognizing that their presence in the region is shaped as much by Latin America's political history as it is by the post-Civil War South. Many of the authors in this issue focus on Latino/ as' explicit and implicit (re)constructions of their identities in response to the persistently racializing and consequent specificities of the exploitative labor and social relations that shape southern society. Certainly, immigrants arrive in the United States with their own hopes, expectations and fears, their minds and bodies marked by differentiated sociocultural experiences and understandings of race in their respective homelands (Dzidzienyo and Oboler, 2005). Jennifer Jones' 
study explores the experiences of Afro-Mexicans and Mestizo Mexicans in the highly segregated context of Winston-Salem, North Carolina. She examines how both groups translate the meanings attributed to race and Blackness in Mexico to produce differentiated racial identities in their new society, one characterized by ongoing Black-White tensions. In so doing, Jones traces the uneven development of Mexicans' relations with African Americans and shows that their consequent production of an identity as a racial(ized) minority is informed by their understandings of African Americans' experiences. She argues for the importance of recognizing such factors as demographics, national origin and immigration policy in shaping the specificities of racialization processes at the local level.

Gabriela Nuñez's study of Latino/as in Kentucky focuses on a different integration strategy - that of the construction of a "Latino Pastoral Narrative" that seeks to counter what anthropologist Leo Chávez has eloquently described as the "Latino Threat Narrative." Based on a close reading of cultural texts, Nuñez analyzes the implications of depicting Latino/a backside workers' love for horses and close relationship to nature, showing how this more "digestible" image contributes to ease their acceptance as "valuable workers." Her discussion shows that to some extent this image humanizes Latino/a workers in the context of draconian laws against "illegal immigrants," even as it simultaneously highlights their closeness to non-humans, ultimately serving to naturalize the logic of Latino/as' permanence in the lower rungs of the social and labor hierarchy of Kentucky. Thus, Nuñez argues that this effort to redefine the meaning of Latinidad ultimately tends to lock Latino/as into specific types of low-paid labor, reinforcing both their exploitation and lack of social mobility, as well as the existing racialized labor hierarchies in the state's horse-racing industry.

Indeed, according to Miranda Cady Hallet, it is important to "conceptualize the construction of whiteness, blackness, and Latinidad rather than simply speaking of whites, blacks, and Latinos as if these were pre-existing social identities." Her article focuses on Salvadoran immigrants' construction of their identity as responsible, independent, "good workers and neighbors" in a small southern town, as a means of establishing their superiority to poor White workers, long considered the "White trash" of rural Arkansas. In so doing, Hallet also suggests that Salvadoran migrant workers seek to distance themselves from negative stereotypes of Latino/as - and of "Mexicans" in particular. This concern contributes to shaping Salvadoran migrants' identities, motivations and choices, while simultaneously establishing their superiority in relation to other non-Latino/a poor workers, thus facilitating their integration. Although the Salvadorans' strategy may to some extent mitigate the racial and class prejudice and discrimination, creating what she calls a "contingent belonging" in a small town context, Hallet argues that it also forces them to work tirelessly under relentlessly exploitative conditions, in order to live up to their enforced self-definition, ultimately reproducing the racial and class hierarchy of neoliberal capitalism. 
The social isolation that Latino/as experience in the US South is thus often forced upon them - whether by the local context in which they live and work, or as a result of their own efforts to circumvent racial prejudice and discrimination by constructing new identities that might help to create a different narrative about themselves. This raises larger questions about the impact and implications of the specificities of the region's racial and ethnic relations for immigrants' experience of integration. Focusing on health research, practice and policies in South Carolina, Clare Barrington, DeAnne Hilfinger Messias and Lynn Weber examine the role of racial and ethnic relations in constructing and shaping existing inequalities among groups. Using community-based research among Latino/a immigrants in West Columbia, South Carolina, they discuss the extent to which the local racial and ethnic context reinforces Latino/as' social isolation, and exacerbates the impact of language and communication barriers. Their article clearly shows the extent to which Latino/as' social isolation, together with the deep fear of the immigrants in their host society, and the competition for jobs, housing and social and educational resources, significantly impacts on the health and well-being of Latino/as. Their study thus challenges public health research practice and policies that limit their frameworks to individual health status and health behaviors, arguing that these "fail to provide a complex, textured understanding of the experiences of Latino immigrants and the broader context shaping their health outcomes." Among the nuanced understandings their research elicits, Barrington, Hilfinger Messias and Weber document, for example, that despite the area's ongoing racial tensions between Whites and Blacks, the presence of "Latino outsiders" has led to the emergence of a "West Columbia people identity" that includes both Blacks and Whites. Thus, on the one hand, the presence of Latino/as is reinforcing Blacks as Americans/insiders, while on the other it is contributing both to refine traditional White/Black relations and to create new racial tensions and antagonism between African Americans and Latino/a immigrants in the area. Moreover, although their research focus is specifically on health, the authors also suggest that in other areas, such as educational and language policies, or jobs, the presence of Latino/ as in West Columbia is deeply impacting and reshaping the broader discourse, respectively, for Whites and Blacks, as well as for Latino/as. Ultimately, the authors argue that current health research and policies should be guided by "deeper understandings of how macro-level structures and social relations impact health and well-being in immigrant and minority communities."

The extent of the significance of institutions and their beliefs, discourse and policies in shaping both the possibility and the conditions for Latino/as' integration is demonstrated in Laura López-Sanders' article about the role of religion and the church in both contributing to and hindering Latino/as' integration. The importance of religion to immigrant integration, particularly in the Bible Belt states, cannot be underestimated, providing as it does solace, protection and guidance to the immigrants in their new environment. As 
López-Sanders writes, in contrast to other parts of the country, "religion in the South is a fundamental organizing principle of society and of immigrant incorporation. Religious organizations can promote or hinder the integration of immigrants in other mainstream institutions and in Southern society as a whole." On the basis of her research in the Greenville-Spartanburg-Anderson region of South Carolina, López-Sanders presents a comparative study of two Catholic and one non-denominational Protestant church, to examine the role of religious organizations in the integration of distinct Latino immigrant groups. She argues that "distinctions within rather than between Protestant and Catholic congregations drive the effects that churches have on Latinos' divergent pathways." At the same time, she presents a nuanced analysis of the experiences of Colombian, Mexican and Guatemalan immigrants, showing their differentiated incorporation, based on each group's particular ethnic, racial, social and religious differences. In assessing their varied forms of integration into their respective congregations, for example, she notes that in contrast to Colombian immigrants in the region, who followed a "straight-line assimilation trajectory," and to Mexican immigrants, whose path to incorporation was less linear, the indigenous Guatemalan immigrants in her study "started an ethnic church, which they used to insulate themselves from racial ostracism." These distinctions highlight the significance of nuanced research on Latino/as in the South, for in addition to attending to the significant comparative specificities of each church, as López-Sanders argues, "[et]hnic succession in churches is, in these cases, intrinsically tied to the status of the immigrant groups in the community, the responses of other groups towards immigrant newcomers, and the religious preferences of immigrants."

Indeed, since the 1970s, both the institutional integration and the understanding of the lived experiences of Latin American and Caribbean immigrants in the US context has been largely homogenized and shaped by the ethnic label "Hispanic" (or "Latino," its more recent grassroots alternative) as defined by Directive 15 of the Office of Management and Budget. Thus, in addition to their religious preferences and beliefs, López-Sanders' study also emphasizes the significance of attending to the particularities of each immigrant group's national, racial and class differences, and their time and place of arrival, in order to best understand the role of religion and church institutions in shaping and impacting on the extent of immigrants' integration today.

Alan LeBaron's article on the Maya in Canton Georgia, in the Southeast, and more generally in the United States, focuses precisely on the specificities of the term Latino/a and its implications for indigenous immigrants' integration into US society. It is based on his longitudinal study of Guatemalan Maya immigrants, whose history in their homeland has been impacted by the often-violent inter-ethnic relations in Guatemala, where the historic "ladino" dominance has long been grounded in racist stereotypes against Maya people and culture. Perhaps not surprisingly, then, the idea of 
joining non-indigenous Latin American and Caribbean immigrants and incorporating as "Latino/as" in the South - or indeed in the United States is, as Alan LeBaron argues in his study, neither welcomed nor possible for many Maya, without first "overcoming internal legacies of colonialism in which the Americas share a common past." The result, however, as Lebaron cogently shows, is the Maya's ongoing struggle for their rights and dignity, as well as for the affirmation of their identity in the often hostile contexts of both the US Latino/a community and the broader society as a whole.

Indigenous people's lack of rights in the Americas is, as Lebaron emphasizes, deeply rooted in the hemisphere's shared legacy of colonialism. Although Latino/as in the US context continue to struggle for rights, the meanings that Latin American indigenous peoples attribute to citizenship in the United States are particularly helpful in signifying all immigrants' understanding of transnational belonging to both their respective homelands and their new society. Ella Schmidt's article focuses on the transnational construction of citizenship from below, among an institutionally disenfranchised indigenous immigrant population in Florida, a state generally not considered part of the traditional South. Although this article was not presented at the conference on which this special issue is based, the significance of transnationalism and civic and political participation addressed by Schmidt are germane to the discussion at hand. Focusing on the Hñähñu immigrants in Clearwater, Central Florida, Schmidt's study describes the indigenous Mexican immigrants' construction of citizenship from below and the transnational grounded meanings they attribute to belonging in a southern context of discrimination. In so doing, she discusses the process through which the Hñäñu redefine the meaning of citizenship, adapting their ancient forms of governance "in an effort to socially and culturally survive as citizens with agency."

Schmidt's study emphasizes the extent to which a transnational cultural identity and traditional values, as well as notions of citizenship and belonging, are important in shaping Latino/a immigrants' daily lives and relations in their host society. In so doing, she raises questions about the relative significance of transnationalism in both immigrants' lives and responses to their racialization, and of the particular local forms of discrimination they encounter in the current context of neoliberal globalization.

In the final article of this issue, Jamie Winders and Barbara Smith take as their point of departure the emphasis that to date has been placed by Latino studies scholars on various demographic, social and economic repercussions of the growing Latino immigrant populations in cities and states of the Southeast. At the same time, they note that there has not been a sustained examination of the implications of the specificities of the region itself in shaping the Latino/a experience. Arguing that the field of Latino studies has "excepted, more than accepted, the traditional South, as a site for critically engaging the nature of 
Latino settlement and experiences," they call attention to the need to examine the "forms, experiences and politics of the combination [of] ... being Latina/o and being southern or being Latina/o in the South." In so doing, their aim is to establish a dialogue between scholars in the fields of the traditional South and Latino studies about the implications of the current "racial, cultural and social dynamics of Latino migration to new southern locales." They exemplify their argument by focusing on the changing nature of Latino/as' transnational practices in the context of current anti-immigrant legislation, the impact of Latino/as' presence on traditional forms of racialization and racism in the Deep South, and the impact of neoliberal globalization and flexible labor practices on Latino/a workers. In so doing, they forcefully demonstrate the extent to which this kind of sustained analysis of Latino/as in/and the South "can yield new insights for Latino studies, which, in turn, can offer critical theoretical and comparative empirical frameworks for understanding immigrants in these new destinations."

Undoubtedly, as all the authors show, the unique history and socio-racial context of the southern states of the United States has shaped the specificities of the Latino/a experience in the region. At the same time, the region itself has simultaneously been forced to begin to confront the implications of some of its practices, in response to Latino/as' growing activism against the multiple injustices they encounter in their everyday lives. Indeed, the emergence of draconian anti-immigrant legislation across the region - together with the immigrants' significant response - has led some to identify the South, once again, as the central site of struggle for rights and equality. Over the past few months, for example, Latino/as have affirmed their dignity and rights in demonstrations such as the March 8, 2012 day of action against Alabama's HB 56. In a recent article, the event was described as a "replication of the iconic African-American civil rights march from Selma to Montgomery," by Juan Cartagena (2012), President and General Counsel of LatinoJustice-PRLDEF. The day of action ended with Latino/as, African Americans, and Whites joining together at the St. Jude Communal Center in Montgomery to repudiate the anti-immigrant stance of the state of Alabama. Moreover, identifying "Latino youth as 'the future of activism', "Cartagena notes the moving speech by one young Latino - a DREAM Act student, who fearlessly declared his undocumented status.

Forbidden from attending universities and continuing their studies, hundreds of thousands of dreamers - undocumented students across the South and throughout the country - are being forcefully excluded from educational institutions of higher learning. But here too, as Lorgia García Peña's essay describes in the Reflexiones Pedagógicas section of this issue, new alternative institutional responses are emerging, such as the "Freedom University" in Athens, Georgia, which "provides college instruction to qualified students regardless of their immigration status." As one of its founding members, García Peña describes this volunteer organization and its effort to bring together "scholars, community organizations, students, dreamers, and undocumented 
immigrants of diverse backgrounds in a coalition of new human rights advocates."

Thus, focused on the migration of Latino/as in the US South, this double issue serves to highlight once again the uniqueness of the location that Latino/as occupy as a social group and political actor in contemporary US society. This position, defined by the three traditional power factors in the US historical experience - race, class and national origin - is one of quintessential ambiguity, which transcends even traditional understandings of immigrants as "foreign others." In the context of the unambiguous history of racial discrimination and labor exploitation in the US South, Latino/as' ambiguous place goes beyond the traditional rejection of "the immigrant foreigner." It is an important reminder of the growing significance of the "stranger" in modern social dynamics, one who is needed yet unwanted, one who is present yet unfamiliar - society's undecidable, to use Zygmunt Bauman's (1993) evocative term.

The overall import of both the specificities and cumulative Latino/a experiences discussed in the following pages also calls attention to the significant privatization of experience, which has become the hallmark of neoliberal globalization, as personal experience is refracted through the prism of traditional racism and ethnic discrimination. Certainly, the dialectic between community belonging and the creation of networks for adapting to new situations and social settings frames the concrete choices of Latinos in the United States under conditions of endemic uncertainty. But insofar as neoliberalism breaks up all traditional social bonds, including those of citizenship and belonging, the position of Latino/as as the "stranger" in the US South also sheds light on the current shifts in the meaning of citizenship and belonging.

Saludos!

\section{References}

Bauman, Z. (1993). Modernity and Ambivalence. London: Polity Press.

Cartagena, J. (2012). Latino Youth are the Future of Activism - A View from the Selma March. LatinoJustice.org; March 9; http://latinojustice.org/briefing_room/press_ releases/latino_youth_and_the_future_of_activism/.

Dzidzienyo, A. and Oboler S. (2005). Neither Enemies Nor Friends: Latinos, Blacks, AfroLatinos. New York, NY: Palgrave.

Petri, C. (2009). 19 February. Translating Disaster. American Prospect, http://prospect.org/ article/translating-disaster, accessed 1 February 2012.

Suzanne Oboler

John Jay College of Criminal Justice, City University of New York, NY.

E-mail: soboler@jjay.cuny.edu 